\title{
Analisis Struktur Vegetasi di Kecamatan Ampel Kabupaten Boyolali
}

\author{
MARIDI ${ }^{1 *}$, ALANINDRA SAPUTRA ${ }^{1}$, PUTRI AGUSTINA ${ }^{2}$ \\ ${ }^{1}$ Prodi Pendidikan Biologi FKIP Universitas Sebelas Maret \\ Jl. Ir Sutami 36 A, Surakarta, 57126, Indonesia \\ ${ }^{2}$ Prodi Pendidikan Biologi FKIP Universitas Muhammadiyah Surakarta \\ Jl. A. Yani Tromol Pos 1, Pabelan Kartasura, Surakarta, Jawa Tengah 57102 \\ *email: maridi@staff.uns.ac.id; maridi_uns@yahoo.co.id
}

Manuscript received: 12 Desember 2014 Revision accepted: 25 Januari 2015

\begin{abstract}
Tujuan penelitian ini antara lain: (1) mengetahui struktur dan komposisi vegetasi baik pohon maupun vegetasi penutup lantai (lower crop community-LCC) di lokasi kajian AMDAL kecamatan Ampel Kabupaten Boyolali; serta (2) mengetahui pengaruh indeks nilai penting dan indeks diversitas vegetasi terhadap kondisi lingkungan di sekitar lokasi kajian AMDAL kecamatan Ampel kabupaten Boyolali. Penelitian dilaksanakan di lokasi kajian AMDAL kecamatan Ampel kabupaten Boyolali pada bulan Juni sampai Juli 2013. Penelitian dilaksanakan dalam beberapa tahap antara lain: (1) survei (pene-litian pendahuluan; (2) penentuan area kajian (unit sampling); (3) pengambilan data lapangan; serta (4) analisis data. Hasil penelitian menunjukkan bahwa untuk vegetasi pohon, diperoleh 46 spesies yang termasuk ke dalam 24 famili. Jenis pohon yang pa-ling banyak ditemukan adalah Capsicum frutescens (cabe rawit) yang berjumlah 3655 individu tiap $1600 \mathrm{~m}^{2}$. Kontribusi spesies pohon yang terbesar ditunjukkan oleh indeks nilai penting (INP) tertinggi adalah Capsicum frutescens. Indeks diversitas/keaneka-ragaman vegetasi pohon di lokasi adalah 0,9864 (rendah). Untuk vegetasi penutup lantai (LCC) ditemukan 80 spesies yang termasuk 27 famili. Cacah individu terbanyak adalah Wedelia montana sebanyak 3234608 individu per $400 \mathrm{~m}^{2}$. Indeks diversitas vegetasi LCC adalah 1,144822 (melimpah).
\end{abstract}

Keywords: struktur vegetasi, LCC, Boyolali, INP

\section{LATAR BELAKANG}

Ekosistem alam merupakan satu ke-satuan habitat alami tempat bernaung-nya seluruh makhluk (manusia, tumbuhan, dan hewan). Makhluk tersebut masing-masing berada dalam suatu komunitas tertentu, dimana mereka saling berinter-aksi satu dengan lainnya. Ekosistem memiliki manfaat yang besar untuk peme-nuhan kebutuhan manusia. pemanfaatan sumber alam di ekosistem tersebut tentu-nya akan menyebabkan terjadinya peru-bahan suatu ekosistem, sehingga pada akhirnya akan mengubah komunitasnya. Keadaan ini dapat mempengaruhi kemampuan auto-operasi dari sistem dan kese-imbangan struktur fungsional. Oleh kare-na itu, kesatuan dan keseimbangan struk-tur fungsional ini harus dipertahankan da-lam setiap pemanfaatan dan pengelolaan suatu ekosistem.

Komunitas tumbuhan pada suatu daerah menurut Parejiya et al (2013) me-rupakan fungsi waktu; meskipun altitude, kemiringan, latitude, hujan, dan kelem-baban memegang peran penting dalam pembentukan komunitas tumbuhan dan komposisinya. Variasi keanekaragaman spesies di bawah gradien lingkungan me-rupakan topik penyelidikan ekologi utama dan dijelaskan sebagai interaksi antara iklim, produktivitas, interaksi biotik, heterogenitas habitat, dan sejarah. Penutupan tumbuhan (plant cover) dalam suatu ka-wasan yang terdiri dari beberapa komuni-tas tumbuhan yang membentuk vegetasi.

Vegetasi menurut Maarel (2005) merupakan didefinisikan sebagai suatu sistem yang terdiri dari sekelompok be-sar tumbuhan yang tumbuh dan meng- huni suatu wilayah. Vegetasi juga didefi-nisikan sebagai keseluruhan tumbuhan dari suatu area yang berfungsi sebagai area penutup lahan, yang terdiri dari be-berapa jenis seperti herba, perdu, pohon, yang hidup bersamasama pada suatu tempat dan saling berinteraksi antara satu dengan yang lain, serta lingkungannya dan memberikan kenampakan luar vege-tasi (Agustina, 2008; Maryantika, 2010; Susanto, 2012).

Vegetasi memegang peran penting pada banyak proses yang berlangsung di ekosistem yang diantaranya diungkapkan oleh Smith, et .al (2000) antara lain: (a) penyimpanan dan daur nutrisi; (b) penyim panan karbon; (c) purifikasi air; serta (d) keseimbangan dan penyebaran komponen penting penyusun ekosistem seperti detri-vor, polinator, parasit, dan predator. Pe-rubahan vegetasi menurut Stirling dan Wilsey (2001) berpengaruh penting terha-dap stabilitas, produktivitas, struktur tro-fik, serta perpindahan komponen ekosis-tem. Oleh karena itu, monitoring terhadap perubahan struktur dan komposisi vege-tasi harus dilakukan secara berkala agar diketahui kondisi umum ekosistem di se-kitarnya. Salah satu cara untuk memantau perubahan struktur dan komposisi vegetasi dilakukan melalui analisis vegetasi.

Analisis vegetasi menurut Susanto (2012) merupakan suatu cara mempela-jari susunan atau komposisi jenis dan ben-tuk atau struktur vegetasi. Satuan vegetasi yang dipelajari dalam analisis vegetasi be-rupa komunitas tumbuhan yang merupa-kan asosiasi konkret dari semua spesies tumbuhan yang menempati suatu habitat. Hasil analisis vegetasi tumbuhan disajikan secara deskriptif 
mengenai komposisi spe-sies dan struktur komunitasnya (Indriyan-to, 2008). Struktur suatu komunitas tidak hanya dipengaruhi oleh hubungan antar spesies tetapi juga oleh jumlah individu dari setiap spesies organisme.

Studi kuantitatif vegetasi menurut Win (2011) memberikan deskripsi tentang vegetasi, prediksi dan klasifikasi polanya serta mengetahui kegunaan dan nilai dari spesies. Analisis ini mengindikasikan di-versitas spesies yang menggambarkan dis-tribusi individu spesies dalam suatu habi-tat.

Struktur komunitas tumbuhan me-miliki sifat kualitatif dan kuantitatif se-hingga dalam deskripsi struktur komunitas tumbuhan dapat dilakukan secara kua-litatif dengan parameter kualitatif atau secara kuantitatif dengan parameter ku-antitatif (Indriyanto, 2008). Namun, persoalan yang sangat penting dalam analisis komunitas adalah bagaimana cara men-dapatkan data terutama data kuantitatif dari semua spesies tumbuhan yang me-nyusun komunitas, parameter kuantitatif dan kualitatif apa saja yang diperlukan, penyajian data, dan interpretasi data agar dapat mengemukakan komposisi floristik serta sifat-sifat komunitas tumbuhan se-cara utuh dan menyeluruh.

Kabupaten Boyolali merupakan sa-lah satu dari 35 kabupaten/kota di propin-si Jawa Tengah. Posisi geografis wilayah kabupaten Boyolali merupakan kekuatan yang dapat dijadikan sebagai modal pem-bangunan daerah karena berada pada se-gitiga wilayah Yogyakarta-SoloSemar-ang (Joglosemar) yang merupakan tiga kota besar yang utama di wilayah Jawa Tengah-DI Yogyakarta. Hal itulah yang menjadi dasar pengembangan potensi daerah kabupaten Boyolali, terutama pada sektor perekonomian dan industri menjadi sangat besar (BKPM Kabupaten Boyolali, 2012). Kabupaten Boyolali terdiri dari 19 Kecamatan salah satunya adalah keca-matan Ampel.

Kecamatan Ampel merupakan salah satu wilayah yang diresmikan sebagai Ka-wasan Industri Tekstil Garmen oleh Pe-merintah Kabupaten Boyolali. Jaminan rasa aman dan iklim usaha yang kondusif menjadi salah satu daya tarik bagi se-jumlah investor untuk menanamkan mo-dal di Kawasan Industri Ampel. Selain itu, kondisi geografis juga menjadi per-timbangan utama dipilihnya kecamatan Ampel sebagai kawasan industri terutama tekstil (Situs Resmi Pemerintah Kabu-paten Boyolali, 2012). Pengembangan kawasan industri Ampel sebagai daerah sentra industri tekstil tentunya harus me-nunggu hasil uji kelayakan, kajian AM-DAL, dan Detail Engineering Detail (DE-D). Oleh karena itu, analisis vegetasi di lokasi kajian AMDAL Kecamatan Ampel Kabupaten Boyolali merupakan salah satu upaya yang harus dilakukan sebelum ka-wasan ini dikembangkan lebih lanjut.

Tujuan penelitian ini antara lain: (1) mengetahui struktur dan komposisi vege-tasi pohon yang terdapat di lokasi kajian AMDAL kecamatan Ampel kabupaten Boyolali; (2) mengetahui struktur dan komposisi vegetasi penutup lantai (lower crop community-LCC) di lokasi kajian AMDAL kecamatan Ampel kabupaten Boyolali; serta (3) menghitung indeks di-versitas vegetasi pohon dan LCC di lokasi kajian AMDAL kecamatan Ampel kabu-paten Boyolali dan menganalisis penga-ruhnya terhadap kondisi lingkungan seca-ra umum. Parameter yang diukur pada penelitian ini adalah jenis dan jumlah individu spesies tumbuhan baik pohon mau-pun LCC, densitas atau kerapatan tiap jenis, frekuensi hadirnya individu spesies dalam plot yang diteliti, indeks nilai penting (INP), serta indeks diversitas (keane-karagaman).

\section{METODE}

\section{Deskripsi Lokasi Penelitian}

Penelitian ini dilaksanakan di lokasi kajian AMDAL kecamatan Ampel ka-bupaten Boyolali. Batas-batas wilayah kecamatan Ampel yaitu: kabupaten Se-marang (Utara dan Selatan), kecamatan Cepogo (Timur), serta kecamatan Selo dan kabupaten Magelang (Barat). Kecamatan Ampel terletak pada ketinggian 520-1840 meter diatas permukaan laut dan memiliki temperatur udara ratarata antara $26^{\circ} \mathrm{C}-30^{\circ} \mathrm{C}$. Luas wilayah kecamat-an Ampel adalah 9.039,1168 Ha. Ke-camatan Ampel terdiri dari 20 desa yaitu: Urutsewu, Gondangslamet, Ngampon, Ngenden, Selodoko, Candi, Sidomulyo, Ngargosari, Banyuanyar, Seboto, Tanduk, Gladagsari, Kembang, Candisari, Nga-grong, Ngargoloko, Kaligentong, Ngadirojo, Sampetan, dan Jlarem. Peta Lokasi Kecamatan Ampel dapat dilihat pada Gambar 1.

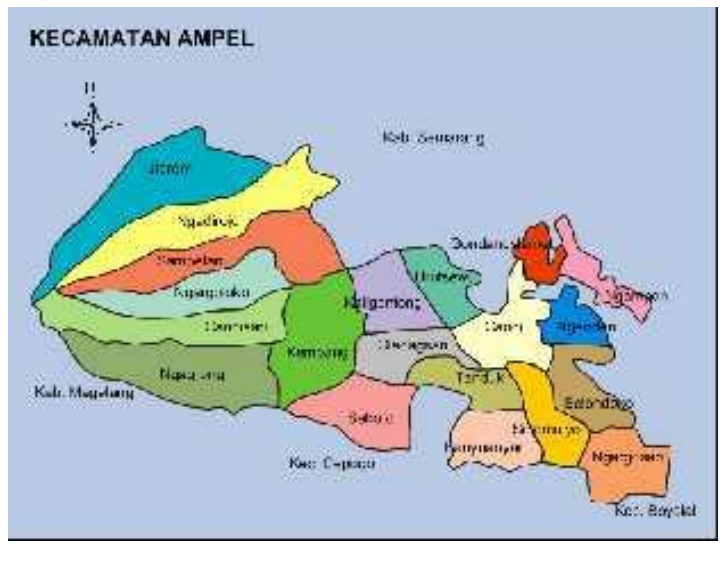

Gambar 1. Wilayah Kecamatan Ampel

\begin{abstract}
Alat dan Bahan
Beberapa peralatan yang digunakan pada penelitian ini antara lain tali sepan-jang $80 \mathrm{~m}$ sebagai alat untuk membuat plot (plotting), pasak untuk memperkuat plot yang digunakan dalam sampling, her-barium kit untuk menyimpan dan menga-wetkan spesimen yang ditemukan pada setiap lokasi sampling, rol meter untuk mengukur jarak dan diameter dalam sam-pling pohon, kompas sebagai penunjuk arah, penggaris untuk pengukuran panjang atau diameter tumbuhan, log book untuk mencatat segala hal yang teramati di lokasi sampling, kamera sebagai alat dokumentasi, serta alat tulis. Peta diper-lukan sebagai petunjuk dalam pelaksa-naan survei dan pengambilan data.
\end{abstract}




\section{Survei (Penelitian Pendahuluan)}

Survei dilaksanakan untuk menge-tahui kondisi lapangan tempat pengam-bilan data akan dilaksanakan. Kegiatan yang dilaksanakan pada tahap ini antara lain pencarian peta lokasi penelitian me-liputi peta tematik cetak maupun peta da-lam bentuk foto udara.

\section{Penentuan Area Kajian (Unit Sampling)}

Pada tahap ini, dilakukan penentuan unit sampling dan luas area pengambilan data. Penentuan area pengambilan data dilakukan dengan mempelajari peta te-matik cetak dan foto udara untuk kemu-dian mengetahui luas area yang dapat diteliti sehingga diketahui jumlah unit sampling. Luas area kajian (unit sam-pling) ditentukan berdasarkan hasil ana-lisis terhadap peta tematik dan foto udara sehingga dapat diketahui daerah yang termasuk daerah pertanian (crop area), daerah bebas (free area), dan daerah perumahan (building area). Daerah yang dapat diteliti dalam kegiatan sampling adalah daerah bebas (free area).

Berdasarkan kajian terhadap peta lokasi penelitian, diketahui luas keseluru-han kecamatan Ampel adalah Luas Area Sampai Jumlah Titik.

\section{Pengambilan Data Lapangan}

Pengambilan data lapangan dila-kukan untuk mengumpulkan data berupa jenis dan jumlah individu vegetasi baik yang berupa pohon maupun vegetasi penutup tanah (lower crop community atau LCC). Pada tahap pengambilan data lapangan, ditentukan lokasi pengambilan sampel berdasarkan hasil pada tahap penentuan unit sampling dan lokasi jalur yang telah disurvei atau unit contoh (Sori-anegara dan Indrawan, 1998 dalam Agus-tina, 2008). Teknik sampling yang dilaku-kan dalam pengambilan data ini adalah simple random sampling (acak seder-hana), yaitu pengambilan sampel dengan melakukan pengundian terhadap semua area (Fachrul, 2007). Setelah diketahui jumlah dan lokasi titik yang digunakan dalam pengambilan sampel, kemudian disusun desain unit jalur penelitian yang berguna untuk menentukan rute atau jalur untuk setiap titik. Pada setiap titik, dibuat petak ukur (plot) berukuran $20 \times 20$ meter untuk menghitung vegetasi berupa pohon dan dengan sub plot $0,5 \times 0,5$ meter untuk menghitung vegetasi berupa LCC. Penca-tatan dilakukan dengan menuliskan jenis dan cacah individu masing-masing jenis tumbuhan ke dalam tabel pengamatan kemudian dilakukan identifikasi jenis tumbuhan baik pohon maupun LCC.

\section{Analisis Data}

Analisis data digunakan untuk mengetahui kontribusi masing-masing spesies dalam area yang diteliti. Analisis vegetasi baik pohon maupun LCC menggunakan Indeks Nilai Penting (INP). INP diperoleh dari penggabungan nilai relatif dari para-meter ekologi yang diukur yaitu densitas dan frekuensi. Prosedur penghitungan INP akan diuraikan sebagai berikut:

1. Perhitungan Indeks Nilai Penting atau INP

Densitas Mutlak Jenis (DMi)

a) Densitas Relatif Jenis (DRi)

$$
D M(i)=\frac{\sum \text { Individu_suatu_jenis_(i) }_{\text {S }}}{\sum \text { Total_Luas_Area }_{\text {L }}}
$$

$$
D R=\frac{D M(i)}{D M{ }_{1} \text { total_seluruh_spesies }} \times 100 \%
$$

b) Frekuensi Mutlak Jenis (Fmi)

$$
F M(i)=\frac{\sum J u m l a h_{-} \text {satuan_plot_yang_diduduki_oleh_spesies }(i)}{\sum J u m l a h_{-} \text {total_plot }}
$$

c) Frekuensi Relatif Jenis i (Fri)

$$
F R(i)=\frac{\text { Frekuensi_mutlak_jenis }(i)}{\text { Frekuensi_total_seluruh_jenis }} \times 100 \%
$$

d) Indeks Nilai Penting (INP)

INP = DR (i) + FR (i) ............(untuk tingkat tiang dan pohon)

2. Perhitungan Indeks Keanekaragaman Jenis

Keanekaragaman jenis dan keman-tapan komunitas dianalisis menggunakan indeks Shannon-Weacer (Indriyanto, 2008$)$ sebagai berikut.

$$
\mathrm{H}^{\prime}=-\sum\{(\mathrm{n} . \mathrm{i} / \mathrm{N}) \log (\mathrm{n} . \mathrm{i} / \mathrm{N})\}
$$

dengan,

$$
\begin{aligned}
& \mathrm{H}^{\prime} \quad \text { = Indeks Shannon / indeks keanekaragaman } \\
& \mathrm{n} . \mathrm{i}=\text { nilai penting dari tiap spesies } \\
& \mathrm{N} \quad=\text { total nilai penting }
\end{aligned}
$$

\section{HASIL}

Struktur dan Komposisi Vegetasi di Lokasi Kajian AMDAL Kecamatan Ampel Ka-bupaten Boyolali Pada 61 titik di lokasi kajian AMDAL Kecamatan Ampel Kabupaten Boyolali yang diteliti, ditemukan total 46 spesies pohon yang termasuk ke dalam 24 suku (famili) 
yang cacah individunya setiap $1600 \mathrm{~m}^{2}$ disajikan dalam Tabel 1 .

Tabel 1. Daftar Spesies Vegetasi Pohon yang Terdapat di Lokasi Kajian AMDAL

\begin{tabular}{|c|c|c|c|c|}
\hline No. & Nama spesies & Nama Lokal & Famili & $\begin{array}{c}\text { Cacah individu/1600 } \\
\mathrm{m}^{2}\end{array}$ \\
\hline 1 & Justicia gendarusa & Gandarusa & Acanthaceae & 90 \\
\hline 2 & Annona squamosa & Srikaya & Annonaceae & 28 \\
\hline 3 & Annona muricata & Sirsak & & 1 \\
\hline 4 & Colocasia esculenta & Talas & Araceae & 394 \\
\hline 5 & Cocos nucifera & Kelapa & Arecaceae & 52 \\
\hline 6 & Salacca edulis & Salak & & 1 \\
\hline 7 & Ceiba pentandra & Randu (kapuk) & Bombacaceae & 15 \\
\hline 8 & Durio zibethinus & Durian & & 54 \\
\hline 9 & Carica papaya & Pepaya & Caricaceae & 180 \\
\hline 10 & Ipomea batatas & Ubi Jalar (Ketela rambat) & Convolvulaceae & 90 \\
\hline 11 & Manihot utilisima & Singkong & Euphorbiaceae & 2096 \\
\hline 12 & Riccinus communis & Jarak Kepyar & & 3 \\
\hline 13 & Albizia falcata & Sengon & Fabaceae & 669 \\
\hline 14 & Leucaena glauca & Lamtoro & & 208 \\
\hline 15 & Samanea Saman & Trembesi & & 32 \\
\hline 16 & Parkia speciosa & Petai & & 10 \\
\hline 17 & Vigna sinensis & Kacang Panjang & & 197 \\
\hline 18 & Arachis hypogea & Kacang Tanah & & 1 \\
\hline 19 & Dolichos lablab & Kara (Kacang Biduk) & & 4 \\
\hline 20 & Gnetum gnemon & Melinjo & Gnetaceae & 5 \\
\hline 21 & Tectona grandis & Jati & Lamiaceae & 102 \\
\hline 22 & Persea americana & Alpukat & Lauraceae & 25 \\
\hline 23 & Hibiscus tiliaceus & Waru & Malvaceae & 58 \\
\hline 24 & Hibiscus rosa-sinensis & Bunga Sepatu & & 6 \\
\hline 25 & Melia azedarach & Mindi & Meliaceae & 35 \\
\hline 26 & Switenia mahagoni & Mahoni & & 6 \\
\hline 27 & Artocarpus heterophyllus & Nangka & Moraceae & 89 \\
\hline 28 & Artocarpus altilis & Sukun & & 10 \\
\hline 29 & Ficus sp. & Beringin & & 2 \\
\hline 30 & Musa paradisiaca & Pisang & Musaceae & 651 \\
\hline 31 & Psiduim guajava & Jambu Biji & Myrtaceae & 3 \\
\hline 32 & Syzygium aqueum & Jambu Air & & 4 \\
\hline 33 & Syzygium cumini & Duwet & & 3 \\
\hline 34 & Pterocarpus indicus & Angsana & Papilionaceae & 2 \\
\hline 35 & Dalbergia latifolia & Sono Keling & & 1 \\
\hline 36 & Zea mays & Jagung & Poaceae/Graminae & 1505 \\
\hline 37 & Neolamarckia cambada & Jabon & Rubiaceae & 130 \\
\hline 38 & Coffea arabica & Kopi & & 134 \\
\hline 39 & Citrus histrix & Jeruk Purut & Rutaceae & 1 \\
\hline 40 & Dimocarpus longan & Kelengkeng & Sapindaceae & 1 \\
\hline 41 & Capsicum frustesens & Cabe Rawit & Solanaceae & 3655 \\
\hline 42 & Solanum torvum & Terong Pipit & & 18 \\
\hline 43 & Nicotiana tabaccum & Tembakau & & 337 \\
\hline 44 & Solanum melongena & Terong & & 1 \\
\hline 45 & Zingiber officinale & Jahe & Zingiberaceae & 194 \\
\hline 46 & Alpinia purpurata & Lengkuas Merah & & 7 \\
\hline
\end{tabular}



Tabel 1 menunjukkan bahwa jenis tumbuhan yang paling banyak ditemu-kan adalah Capsicum frutescens (cabe rawit) yang berjumlah 3655 individu, Mannihot utilissima (ketela pohon) ber-jumlah 2096 individu, Zea mays (jagung) berjumlah 1505 individu, Albizzia falcata (sengon) berjumlah 669 individu dan Musa paradisiaca (pisang) sebanyak 651 individu. Jika ditinjau dari cacah individu, spesies pohon dengan cacah individu yang paling sedikit adalah Solanum melo-ngena (terong) dari suku Solanaceae, Dimocarpus longan (kelengkeng) dari su-ku Sapindaceae, Citrus histrix (jeruk purut) dari suku
Rutaceae, Dalbergia latifolia (sono keling) dari suku Papilio-naceae, serta Arachis hypogaea (kacang tanah) dari suku Fabaceae yang masing-masing hanya ditemukan satu individu.

Jika dilihat dari suku (famili), ma-ka spesies pohon yang paling banyak dite-mukan berasal dari famili Solanaceae (terong-terongan) dengan cacah individu sebanyak 4010 individu sedangkan suku dengan jumlah individu terkecil adalah Rutaceae dan Sapindaceae yang masing-masing berjumlah satu individu (Gambar 1).

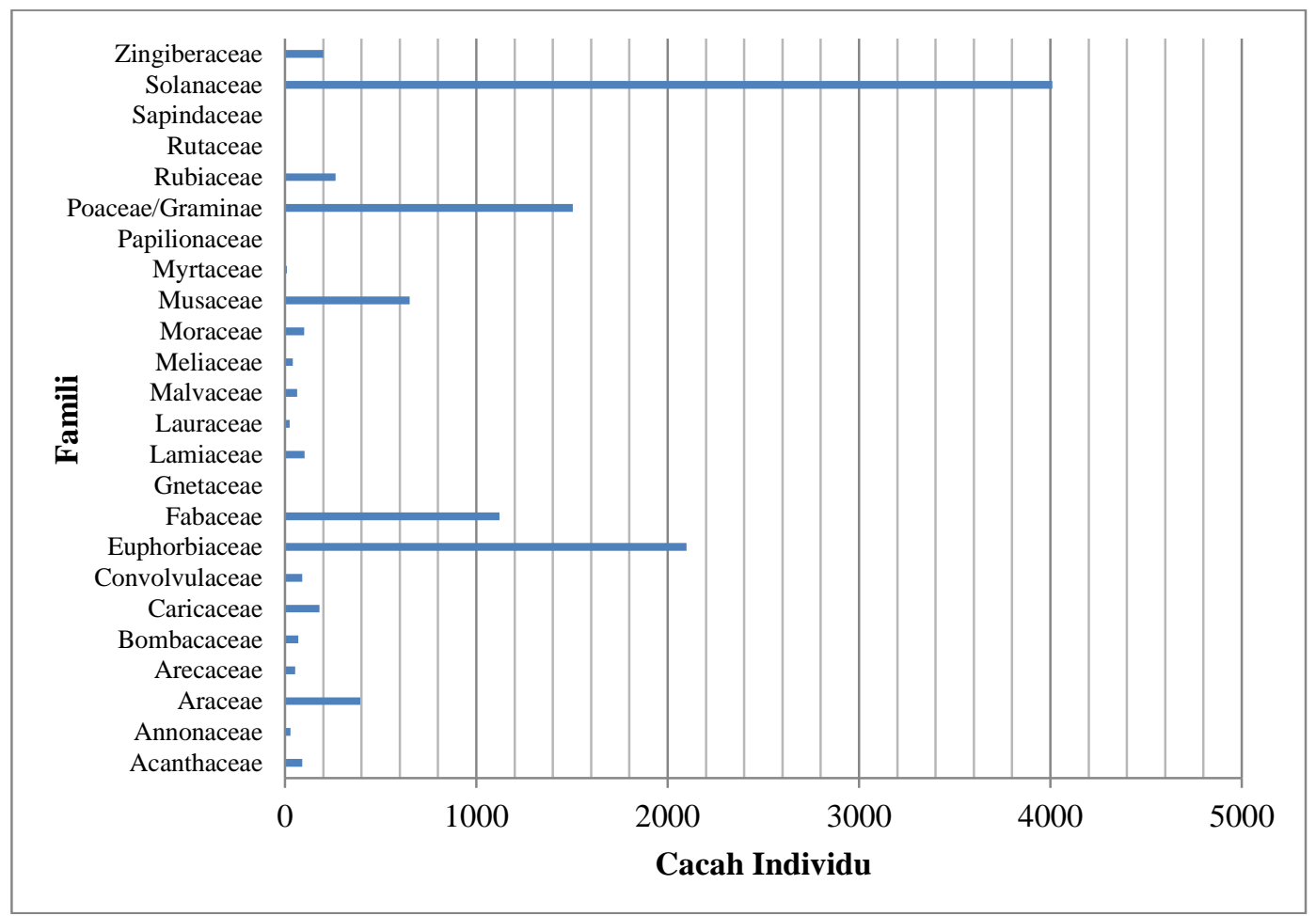

Gambar 1. Grafik Sebaran Cacah Individu setiap Famili

Analisis secara kuantitatif dilakukan terhadap spesies pohon yang ditemukan yaitu densitas tiap jenis, frekuensi, serta indeks nilai penting. Hasil analisis kuantitatif vege- tasi pohon yang terdapat di lokasi kajian AMDAL kecamatan Ampel kabupaten Boyo-lali disajikan secara lengkap pada Tabel 2.

Tabel 2. Daftar Spesies Vegetasi Pohon dan Analisis Secara Kuantitatif yang Terdapat di Lokasi Kajian AMDAL

\begin{tabular}{clccccc}
\hline No. & Nama spesies & D $\left(\mathbf{/ 1 6 0 0 \mathbf { m } ^ { \mathbf { 2 } } )}\right.$ & FR & INP & \multicolumn{1}{c}{ H' } & Rangking \\
\hline 1 & Justicia gendarusa & 90 & 0,0328 & 1,1903 & 0,016943 & 26 \\
2 & Annona squamosa & 28 & 0,0984 & 1,3927 & 0,006549 & 24 \\
3 & Annona muricata & 1 & 0,0164 & 0,1991 & 0,000364 & 40 \\
4 & Colocasia esculenta & 394 & 0,3770 & 7,9190 & 0,05143 & 6 \\
5 & Cocos nucifera & 52 & 0,3934 & 5,0308 & 0,010904 & 11 \\
6 & Salacca edulis & 1 & 0,0164 & 0,1991 & 0,000364 & 41 \\
7 & Ceiba pentandra & 15 & 0,1475 & 1,8460 & 0,003874 & 23 \\
8 & Durio zibethinus & 54 & 0,3934 & 5,0488 & 0,011244 & 10 \\
9 & Carica papaya & 180 & 0,4754 & 7,1335 & 0,029008 & 8 \\
10 & Ipomea batatas & 90 & 0,0984 & 1,9508 & 0,016943 & 21 \\
\hline
\end{tabular}




\begin{tabular}{|c|c|c|c|c|c|c|}
\hline No. & Nama spesies & $\mathrm{D}\left(/ 1600 \mathrm{~m}^{2}\right)$ & FR & INP & $\mathbf{H}^{\prime}$ & Rangking \\
\hline 11 & Manihot utilisima & 2096 & 0,8197 & 28,3716 & 0,13665 & 2 \\
\hline 12 & Riccinus communis & 3 & 0,0164 & 0,2171 & 0,000964 & 36 \\
\hline 13 & Albizia falcata & 669 & 0,9344 & 16,8581 & 0,073481 & 3 \\
\hline 14 & Leucaena glauca & 208 & 0,4754 & 7,3855 & 0,032345 & 7 \\
\hline 15 & Samanea Saman & 32 & 0,2295 & 2,9496 & 0,007318 & 17 \\
\hline 16 & Parkia speciosa & 10 & 0,0984 & 1,2307 & 0,002741 & 25 \\
\hline 17 & Vigna sinensis & 197 & 0,0492 & 2,3435 & 0,031053 & 20 \\
\hline 18 & Arachis hypogea & 1 & 0,0164 & 0,1991 & 0,000364 & 42 \\
\hline 19 & Dolichos lablab & 4 & 0,0164 & 0,2261 & 0,00124 & 35 \\
\hline 20 & Gnetum gnemon & 5 & 0,0656 & 0,8055 & 0,001506 & 29 \\
\hline 21 & Tectona grandis & 102 & 0,3279 & 4,7204 & 0,018703 & 12 \\
\hline 22 & Persea americana & 25 & 0,1475 & 1,9360 & 0,005958 & 22 \\
\hline 23 & Hibiscus tiliaceus & 58 & 0,3443 & 4,5144 & 0,011915 & 13 \\
\hline 24 & Hibiscus rosa-sinensis & 6 & 0,0328 & 0,4342 & 0,001765 & 31 \\
\hline 25 & Melia azedarach & 35 & 0,2951 & 3,7371 & 0,007881 & 15 \\
\hline 26 & Switenia mahagoni & 6 & 0,0328 & 0,4342 & 0,001765 & 32 \\
\hline 27 & Artocarpus heterophyllus & 89 & 0,4754 & 6,3144 & 0,016793 & 9 \\
\hline 28 & Artocarpus altilis & 10 & 0,0820 & 1,0406 & 0,002741 & 28 \\
\hline 29 & Ficus sp. & 2 & 0,0164 & 0,2081 & 0,000674 & 38 \\
\hline 30 & Musa paradisiaca & 651 & 0,8033 & 15,1752 & 0,072198 & 5 \\
\hline 31 & Psiduim guajava & 3 & 0,0492 & 0,5973 & 0,000964 & 30 \\
\hline 32 & Syzygium aqueum & 4 & 0,0328 & 0,4162 & 0,00124 & 33 \\
\hline 33 & Syzygium cumini & 3 & 0,0164 & 0,2171 & 0,000964 & 37 \\
\hline 34 & Pterocarpus indicus & 2 & 0,0164 & 0,2081 & 0,000674 & 39 \\
\hline 35 & Dalbergia latifolia & 1 & 0,0164 & 0,1991 & 0,000364 & 43 \\
\hline 36 & Zea mays & 1505 & 0,2131 & 16,0178 & 0,117606 & 4 \\
\hline 37 & Neolamarckia cambada & 130 & 0,1475 & 2,8811 & 0,022604 & 18 \\
\hline 38 & Coffea arabica & 134 & 0,2459 & 4,0578 & 0,023141 & 14 \\
\hline 39 & Citrus histrix & 1 & 0,0164 & 0,1991 & 0,000364 & 44 \\
\hline 40 & Dimocarpus longan & 1 & 0,0164 & 0,1991 & 0,000364 & 45 \\
\hline 41 & Capsicum frustesens & 3655 & 0,2951 & 36,3203 & 0,158842 & 1 \\
\hline 42 & Solanum torvum & 18 & 0,0820 & 1,1126 & 0,004521 & 27 \\
\hline 43 & Nicotiana tabaccum & 337 & 0,0492 & 3,6036 & 0,046048 & 16 \\
\hline 44 & Solanum melongena & 1 & 0,0164 & 0,1991 & 0,000364 & 46 \\
\hline 45 & Zingiber officinale & 194 & 0,0656 & 2,5066 & 0,030696 & 19 \\
\hline 46 & Alpinia purpurata & 7 & 0,0164 & 0,2531 & 0,002017 & 34 \\
\hline
\end{tabular}

Hasil analisis kuantitatif yang disa-jikan pada Tabel 2 menunjukkan bahwa jika dilihat dari densitasnya, individu de-ngan densitas tertinggi adalah Capsicum frutescens (cabai rawit) yang mencapai 3655 individu per $1600 \mathrm{~m}^{2}$. Selain data densitas, diperoleh pula data berupa frekuensi. Data frekuensi menggambarkan frekuensi kehadiran individu dan meng-gambarkan distribusi individu. Berdasar-kan Tabel 2, spesies yang sering hadir di setiap plot dan distribusinya merata (ada di berbagai lokasi) adalah Albizia falcata.

Parameter kuantitatif lain yang di-hitung pada vegetasi pohon adalah indeks nilai penting (INP). INP adalah parameter kuantitatif yang dapat digunakan untuk menyatakan tingkat dominansi (tingkat penguasaan) spesies-spesies dalam suatu komunitas tumbuhan
(Soegianto, 1994). Berdasarkan Tabel 2, diketahui bahwa di lokasi penelitian didominasi oleh Capsi-cum frutescens atau cabai rawit (INP: 36, 32\%), Mannihot utilissima atau ketela pohon (INP: 28,37\%), Albizia falcata atau sengon (INP: 16,85\%), Zea mays atau jagung (INP: 16,01\%), serta Musa para-disiaca atau pisang (INP: 15,17\%).

Selain vegetasi yang berupa pohon, di lokasi kajian AMDAL kecamatan Am-pel kabupaten Boyolali juga ditemukan spesies yang termasuk pada vegetasi pe-nutup lantai (lower crop community-LCC) Data di lapangan menunjukkan bahwa di lokasi ini ditemukan 80 spesies LCC yang termasuk ke dalam 27 famili. Spesies-spe sies LCC yang ditemukan di lokasi pene-litian disertai nama lokal dan pengelom-pokan berdasarkan familinya disajikan pada Tabel 3. 
Tabel 3. Daftar spesies LCC di lokasi penelitian

\begin{tabular}{|c|c|c|c|}
\hline No. & Nama Spesies & Nama Lokal & Famili \\
\hline 1 & Ruellia tuberosa & Pletekan & Acanthaceae \\
\hline 2 & Adiantum iunulatum & Suplir & Adiantaceae \\
\hline 3 & Achyranthes aspera & Sangketan & \multirow[t]{3}{*}{ Amaranthaceae } \\
\hline 4 & Aismenia americana & & \\
\hline 5 & Amaranthus hibridus & Bayam & \\
\hline 6 & Ageratum conyzoides & Wedusan & \multirow[t]{13}{*}{ Asteraceae } \\
\hline 7 & Bidens pectinata & Ketul & \\
\hline 8 & Blumea balsamina & Sembung & \\
\hline 9 & Eclipta prostata & Urang aring & \\
\hline 10 & Elephantopus scaber & Tapak liman & \\
\hline 11 & Elephantopus spicatus & Tapak liman & \\
\hline 12 & Galinsoga parviflora & Bribil & \\
\hline 13 & Senecio sonchifulius & senecio & \\
\hline 14 & Senecio vulgaris & senecio & \\
\hline 15 & Tagetes erecta L. & kenikir & \\
\hline 16 & Tridax procumbens & Songgolangit & \\
\hline 17 & Vernonia cinerea & Salentrong & \\
\hline 18 & Wedelia montana & Seruni & \\
\hline 19 & Ananas comosus & nanas & Bromeliaceae \\
\hline 20 & Cleome aspera & Mamang & Capparaceae \\
\hline 21 & Drymaria chordata & Randa nunut & Caryophyllaceae \\
\hline 22 & Commelina banghalensis & Gewor & \multirow[t]{5}{*}{ Commelinaceae } \\
\hline 23 & Commelina nudiflora & Gewor & \\
\hline 24 & Aneilema hamiltonianum & Brambangan & \\
\hline 25 & Aneilema nudiflorum & Aur-aur & \\
\hline 26 & Dichrocephala latifolia & Wedahan & \\
\hline 27 & Ipomoea obscura & Ipomea & Convolvulaceae \\
\hline 28 & Cyperus sp & Rumput Teki & \multirow[t]{3}{*}{ Cyperaceae } \\
\hline 29 & Kylinga monocephala & Rumput Kenop & \\
\hline 30 & Cyperus rotundus & Rumput Teki & \\
\hline 31 & Dryopteris cristata & Paku & Dryopteridaceae \\
\hline 32 & Acalypa indica & Kucing-kucingan & \multirow[t]{4}{*}{ Euphorbiaceae } \\
\hline 33 & Phylanthus niruri & Meniran & \\
\hline 34 & Phylanthus urinaria & Meniran & \\
\hline 35 & Euforbia hirta & Patikan kebo & \\
\hline 36 & Arachis hypogaea & Kacang tanah & \multirow[t]{6}{*}{ Fabaceae } \\
\hline 37 & Clitoria ternatea & Kembang telang & \\
\hline 38 & Calopogonium mucunoides & kacang asu & \\
\hline 39 & Desmodium diffusum & Ketipes & \\
\hline 40 & Desmodium uncinatum & Semanggi & \\
\hline 41 & Flemingia congesta & Orok-orok hutan & \\
\hline
\end{tabular}




\begin{tabular}{|c|c|c|c|}
\hline No. & Nama Spesies & Nama Lokal & Famili \\
\hline 42 & Mimosa invisa & Baret & \\
\hline 43 & Mimosa pudica & Putri malu & \\
\hline 44 & Lichen & Lumut Kerak & Graphidaceae \\
\hline 45 & Hyptis brevipes & Godong puser & \multirow[t]{5}{*}{ Lamiaceae } \\
\hline 46 & Hyptis capitata & Hiptis & \\
\hline 47 & Hyptis pectinata & Gringsingan & \\
\hline 48 & Salvia coccinea & Salfia & \\
\hline 49 & Leucas aspera & Leng-lengan & \\
\hline 50 & Marsilea crenata & Semanggi & Marsileaceae \\
\hline 51 & Malvastrum coromandelianum & & Mavaceae \\
\hline 52 & Ludwigia parviflora & Cacabean & Onagraceae \\
\hline 53 & Biophytum reinwardtii & Krambilan & \multirow[t]{2}{*}{ Oxalidaceae } \\
\hline 54 & Oxalis minima & blimbing-blimbingan & \\
\hline 55 & Physalis peruviana & Ceplukan & Solanaceae \\
\hline 56 & Peperomia pellucida & Suruhan & Piperaceae \\
\hline 57 & Bambusa sp & bambu & \multirow[t]{14}{*}{ Poaceae } \\
\hline 58 & Centotheca latifolia & Jukut kidang & \\
\hline 59 & Eleusine indica & Rumput belulang & \\
\hline 60 & Imperata cylindrica & Ilalang & \\
\hline 61 & Insacnea sp. & Insacnea & \\
\hline 62 & Oplismenus burmanii & Rumput gunung & \\
\hline 63 & Oplismenus compositus & Rumput gunung & \\
\hline 64 & Panicum $s p$ & Lampuyangan & \\
\hline 65 & Paspalum canjugatum & Cariangan leutik & \\
\hline 66 & Paspalum sp. & Paspalum & \\
\hline 67 & Pennisetum purpureum & Rumput gajah & \\
\hline 68 & Polytrias amaura & Polytrias & \\
\hline 69 & Psilotrichum trichotomum & Psilotrichum & \\
\hline 70 & Rottboellia exaltata & Jukut Kikisan & \\
\hline 71 & Polygala paniculata & Korejat & Polygalaceae \\
\hline 72 & Portulaca oleracea L. & krokot & Portulacaceae \\
\hline 73 & Riccia fluitans & Riccia & Ricciaceae \\
\hline 74 & Borreria ocymoides & Katumpangan & \multirow[t]{7}{*}{ Rubiaceae } \\
\hline 75 & Borreria stricta & & \\
\hline 76 & Diodia ocymifolia & Birang Hitam & \\
\hline 77 & Lindernia sessiflora & & \\
\hline 78 & Oldenlandia corymbosa & Rumput mutiara & \\
\hline 79 & Richardsonia brasiliensis & Jukut babi & \\
\hline 80 & Spilantes ocimifolia & & \\
\hline
\end{tabular}

Data pada Tabel 3 menunjukkan bahwa spesies LCC yang ditemukan ter-diri dari 27 famili dengan jumlah jenis spesies yang berbeda-beda tiap famili. Famili dengan jumlah jenis spesies terba-nyak antara lain Poaceae dan Asteraceae (13 spesies), Fabaceae (8 spesies), Rubia-ceae (7 spesies), Commelinaceae (5 spe-sies), serta Lamiaceae 
(5 spesies). Sedang kan famili dengan jumlah jenis spesies paling sedikit yaitu Acanthaceae (1 spesi-es yaitu Ruellia tuberosa), Adiantaceae (1 spesies yaitu Adiantum iunulatum), Bro-meliaceae (1 spesies yaitu Ananas commosus), Capparaceae (1 spesies yaitu Cleo-me aspera), Caryopyllaceae (1 spesies yaitu Drymaria cordata), Convolvulace-ae (1 spesies yaitu Ipomoea obscura), Dry opteridaceae (1 spesies yaitu Dryopteris cristata), Graphidaceae (1 spesies yaitu Lichen), Marsileaceae (1 spesies yaitu Marsilea crenata), Mavaceae (1 spesies yaitu Malvastrum coromandelianum), Onagraceae (1 spesies yaitu Ludwigia parviflora), Solanaceae (1 spesies yaitu Physalis peruviana), Piperaceae (1 spesi-es yaitu Peperomia pellucida), Polygala-ceae (1 spesies yaitu Polygala paniculata) Portulacaceae (1 spesies yaitu Portulaca oleracea), serta Ricciaceae (1 spesies yaitu Riccia fluitans).

Analisis kuantitatif juga dilakukan terhadap spesies LCC yang ditemukan. Parameter yang dihitung yaitu densitas, frekuensi, INP, dan indeks diversitas. Ha-sil analisis kuantitatif secara singkat disa-jikan pada Tabel 4.

Tabel 4. Daftar Spesies Vegetasi Penutup Lantai (LCC) dan Analisis Kuantitatif

\begin{tabular}{|c|c|c|c|c|c|}
\hline No. & Nama Spesies & $D\left(/ 1600 m^{2}\right)$ & Frekuensi & INP & H' \\
\hline 1 & Acalypa indica & 2036 & 0,0492 & 0,5810 & 0,000714 \\
\hline 2 & Achyranthes aspera & 708336 & 0,5246 & 12,6803 & 0,078562 \\
\hline 3 & Adiantum iunulatum & 130336 & 0,0820 & 2,1669 & 0,023503 \\
\hline 4 & Ageratum conyzoides & 1619216 & 0,7049 & 23,3402 & 0,124696 \\
\hline 5 & Aismenia americana & 302 & 0,0328 & 0,3774 & 0,000130 \\
\hline 6 & Amaranthus hibridus & 10816 & 0,1967 & 2,3493 & 0,003054 \\
\hline 7 & Ananas comosus & 4 & 0,0164 & 0,1873 & 0,000002 \\
\hline 8 & Aneilema hamiltonianum & 6304 & 0,0492 & 0,6213 & 0,001920 \\
\hline 9 & Aneilema nudiflorum & 2768 & 0,0328 & 0,4007 & 0,000936 \\
\hline 10 & Arachis hypogaea & 100640 & 0,0328 & 1,3247 & 0,019215 \\
\hline 11 & Bambusa sp & 40 & 0,0164 & 0,1876 & 0,000020 \\
\hline 12 & Bidens pectinata & 34336 & 0,0328 & 0,6987 & 0,008070 \\
\hline 13 & Biophytum reinwardtii & 15364 & 0,0328 & 0,5196 & 0,004117 \\
\hline 14 & Blumea balsamina & 896 & 0,0164 & 0,1957 & 0,000345 \\
\hline 15 & Borreria ocymoides & 7728 & 0,0164 & 0,2602 & 0,002289 \\
\hline 16 & Borreria stricta & 43344 & 0,0492 & 0,9710 & 0,009773 \\
\hline 17 & Centotheca latifolia & 2608 & 0,0492 & 0,5864 & 0,000889 \\
\hline 18 & Cleome aspera & 8414 & 0,1803 & 2,1394 & 0,002463 \\
\hline 19 & Clitoria ternatea & 7936 & 0,1803 & 2,1349 & 0,002342 \\
\hline 20 & Calopogonium mucunoides & 1536 & 0,0328 & 0,3890 & 0,000557 \\
\hline 21 & Commelina banghalensis & 55664 & 0,1967 & 2,7727 & 0,011979 \\
\hline 22 & Commelina nudiflora & 165984 & 0,0492 & 2,1289 & 0,028285 \\
\hline 23 & Cyperus rotundus & 259152 & 0,3279 & 6,1921 & 0,039428 \\
\hline 24 & Cyperus sp & 101312 & 0,0328 & 1,3311 & 0,019315 \\
\hline 25 & Desmodium diffusum & 15 & 0,0164 & 0,1874 & 0,000008 \\
\hline 26 & Desmodium uncinatum & 26624 & 0,0164 & 0,4386 & 0,006535 \\
\hline 27 & Dichrocephala latifolia & 10208 & 0,1475 & 1,7818 & 0,002907 \\
\hline 28 & Diodia ocymifolia & 864 & 0,0164 & 0,1954 & 0,000334 \\
\hline 29 & Drymaria chordata & 705472 & 0,2951 & 10,0315 & 0,078362 \\
\hline 30 & Dryopteris cristata & 25280 & 0,0820 & 1,1750 & 0,006259 \\
\hline 31 & Eclipta prostata & 118608 & 0,0492 & 1,6816 & 0,021846 \\
\hline 32 & Elephantopus scaber & 7840 & 0,0328 & 0,4486 & 0,002317 \\
\hline
\end{tabular}




\begin{tabular}{|c|c|c|c|c|c|}
\hline No. & Nama Spesies & D $\left(/ 1600 m^{2}\right)$ & Frekuensi & INP & $\mathbf{H}^{\prime}$ \\
\hline 33 & Elephantopus spicatus & 4144 & 0,0492 & 0,6009 & 0,001333 \\
\hline 34 & Eleusine indica & 68288 & 0,1967 & 2,8919 & 0,014124 \\
\hline 35 & Euforbia hirta & 7648 & 0,1639 & 1,9449 & 0,002268 \\
\hline 36 & Flemingia congesta & 7 & 0,0164 & 0,1873 & 0,000004 \\
\hline 37 & Galinsoga parviflora & 19664 & 0,0820 & 1,1220 & 0,005071 \\
\hline 38 & Hyptis brevipes & 1728 & 0,0492 & 0,5781 & 0,000618 \\
\hline 39 & Hyptis capitata & 1933 & 0,0328 & 0,3928 & 0,000682 \\
\hline 40 & Hyptis pectinata & 9840 & 0,0164 & 0,2802 & 0,002817 \\
\hline 41 & Imperata cylindrica & 128176 & 0,0820 & 2,1465 & 0,023201 \\
\hline 42 & Insacnea sp. & 5280 & 0,0328 & 0,4244 & 0,001646 \\
\hline 43 & Ipomoea obscura & 1600 & 0,0328 & 0,3896 & 0,000577 \\
\hline 44 & Kylinga monocephala & 243424 & 0,4098 & 6,9799 & 0,037660 \\
\hline 45 & Leucas aspera & 1088 & 0,0164 & 0,1975 & 0,000410 \\
\hline 46 & Lichen & 1824 & 0,0164 & 0,2045 & 0,000648 \\
\hline 47 & Lindernia sessiflora & 23392 & 0,0656 & 0,9699 & 0,005866 \\
\hline 48 & Ludwigia parviflora & 224 & 0,0164 & 0,1894 & 0,000099 \\
\hline 49 & Malvastrum coromandelianum & 7696 & 0,0164 & 0,2599 & 0,002281 \\
\hline 50 & Marsilea crenata & 80272 & 0,1803 & 2,8178 & 0,016070 \\
\hline 51 & Mimosa invisa & 1408 & 0,0328 & 0,3878 & 0,000515 \\
\hline 52 & Mimosa pudica & 11232 & 0,1148 & 1,4169 & 0,003154 \\
\hline 53 & Oldenlandia corymbosa & 2560 & 0,0492 & 0,5860 & 0,000874 \\
\hline 54 & Oplismenus burmanii & 255760 & 0,3115 & 5,9728 & 0,039050 \\
\hline 55 & Oplismenus compositus & 4960 & 0,0328 & 0,4214 & 0,001559 \\
\hline 56 & Oxalis minima & 6112 & 0,0820 & 0,9940 & 0,001869 \\
\hline 57 & Panicum $s p$ & 248656 & 0,1803 & 4,4076 & 0,038252 \\
\hline 58 & Paspalum canjugatum & 157328 & 0,2295 & 4,1071 & 0,027156 \\
\hline 59 & Paspalum sp. & 434624 & 0,1803 & 6,1634 & 0,056909 \\
\hline 60 & Pennisetum purpureum & 725024 & 0,3934 & 11,3397 & 0,079721 \\
\hline 61 & Peperomia pellucida & 85264 & 0,2787 & 3,9885 & 0,016859 \\
\hline 62 & Phylanthus niruri & 320 & 0,0164 & 0,1903 & 0,000137 \\
\hline 63 & Phylanthus urinaria & 51040 & 0,4754 & 5,9126 & 0,011166 \\
\hline 64 & Physalis peruviana & 768 & 0,0164 & 0,1945 & 0,000300 \\
\hline 65 & Polygala paniculata & 2688 & 0,0164 & 0,2126 & 0,000912 \\
\hline 66 & Polytrias amaura & 441440 & 0,0492 & 4,7296 & 0,057520 \\
\hline 67 & Portulaca oleracea $L$. & 3504 & 0,0820 & 0,9694 & 0,001151 \\
\hline 68 & Psilotrichum trichotomum & 9600 & 0,0164 & 0,2779 & 0,002758 \\
\hline 69 & Richardsonia brasiliensis & 21280 & 0,0164 & 0,3882 & 0,005419 \\
\hline 70 & Riccia fluitans & 2800 & 0,0164 & 0,2137 & 0,000946 \\
\hline 71 & Rottboellia exaltata & 592 & 0,0328 & 0,3801 & 0,000238 \\
\hline 72 & Ruellia tuberosa & 1760 & 0,0164 & 0,2039 & 0,000628 \\
\hline 73 & Salvia coccinea & 31872 & 0,0656 & 1,0500 & 0,007588 \\
\hline 74 & Senecio sonchifulius & 256 & 0,0164 & 0,1897 & 0,000112 \\
\hline
\end{tabular}




\begin{tabular}{|c|l|c|c|c|c|}
\hline No. & \multicolumn{1}{|c|}{ Nama Spesies } & $\mathbf{D}\left(\mathbf{/ 1 6 0 0 \mathbf { m } ^ { \mathbf { 2 } } )}\right.$ & Frekuensi & INP & H' \\
\hline 75 & Senecio vulgaris & 57808 & 0,0492 & 1,1076 & 0,012351 \\
\hline 76 & Spilantes ocimifolia & 480 & 0,0164 & 0,1918 & 0,000197 \\
\hline 77 & Tagetes erecta L. & 2352 & 0,0328 & 0,3967 & 0,000811 \\
\hline 78 & Tridax procumbens & 8192 & 0,0328 & 0,4519 & 0,002407 \\
\hline 79 & Vernonia cinerea & 1056 & 0,0328 & 0,3845 & 0,000399 \\
\hline 80 & Wedelia montana & 3234608 & 0,8033 & 39,7155 & 0,157321 \\
\hline
\end{tabular}

Hasil analisis kuantitatif pada Ta-bel 4 menunjukkan bahwa spesies yang memiliki densitas tertinggi adalah Wide-lia montana yaitu 3234608 individu per $400 \mathrm{~m}^{2}$. Selain itu, beberapa spesies me-miliki densitas tertinggi yaitu: Ageratum conyzoides (1619216 individu/400 $\mathrm{m}^{2}$ ), Pennisetum purpureum (725024 indi-vidu/400 $\mathrm{m}^{2}$ ), Achyranthes aspera (708 336 individu $\left./ 400 \mathrm{~m}^{2}\right)$, Drymaria chor-data $\left(705472\right.$ individu $\left./ 400 \mathrm{~m}^{2}\right)$, serta Polytrias amaura (441440 individu/400 $\mathrm{m}^{2}$ ). Sedangkan spesies dengan densitas terendah adalah Ananas commosus dengan jumlah 4 individu per $400 \mathrm{~m}^{2}$.

Jika dilihat pada setiap famili,ma ka diperoleh famili dengan densitas ter-tinggi yaitu Asteraceae $(12772,44)$, Poa-ceae (6205,94), Amaranthaceae (1798, 635), Caryophyllaceae $(1763,68)$, serta Cyperaceae $(1509,72)$.
Sedangkan fami-li dengan densitas terendah adalah Bromeliaceae (0,01). Sebaran densitas per $400 \mathrm{~m}^{2}$ untuk setiap famili dapat disa-jikan pada Gambar 2.

Parameter kuantitatif lain yang diukur untuk vegetasi LCC pada pene-litian ini adalah frekuensi. Tabel 4 menunjukkan bahwa spesies yang sering hadir di setiap plot dan distribusinya me rata adalah Wedelia montana (0,8033), Ageratum conyzoides (0,7049), Achy-ranthes aspera (0,5246), Phylanthus urinaria (0,4754), serta Kylinga mono-cephala (0,4098). Sedangkan jika dianalisis setiap famili, famili dengan freku-ensi tertinggi adalah Asteraceae (0,88 52), Poaceae (0,8033), Amaranthaceae $(0,6230)$, Cyperaceae $(0,5410)$, serta Euphorbiaceae (0,5082). Sebaran freku-ensi untuk setiap famili dapat dilihat pada Gambar 3.

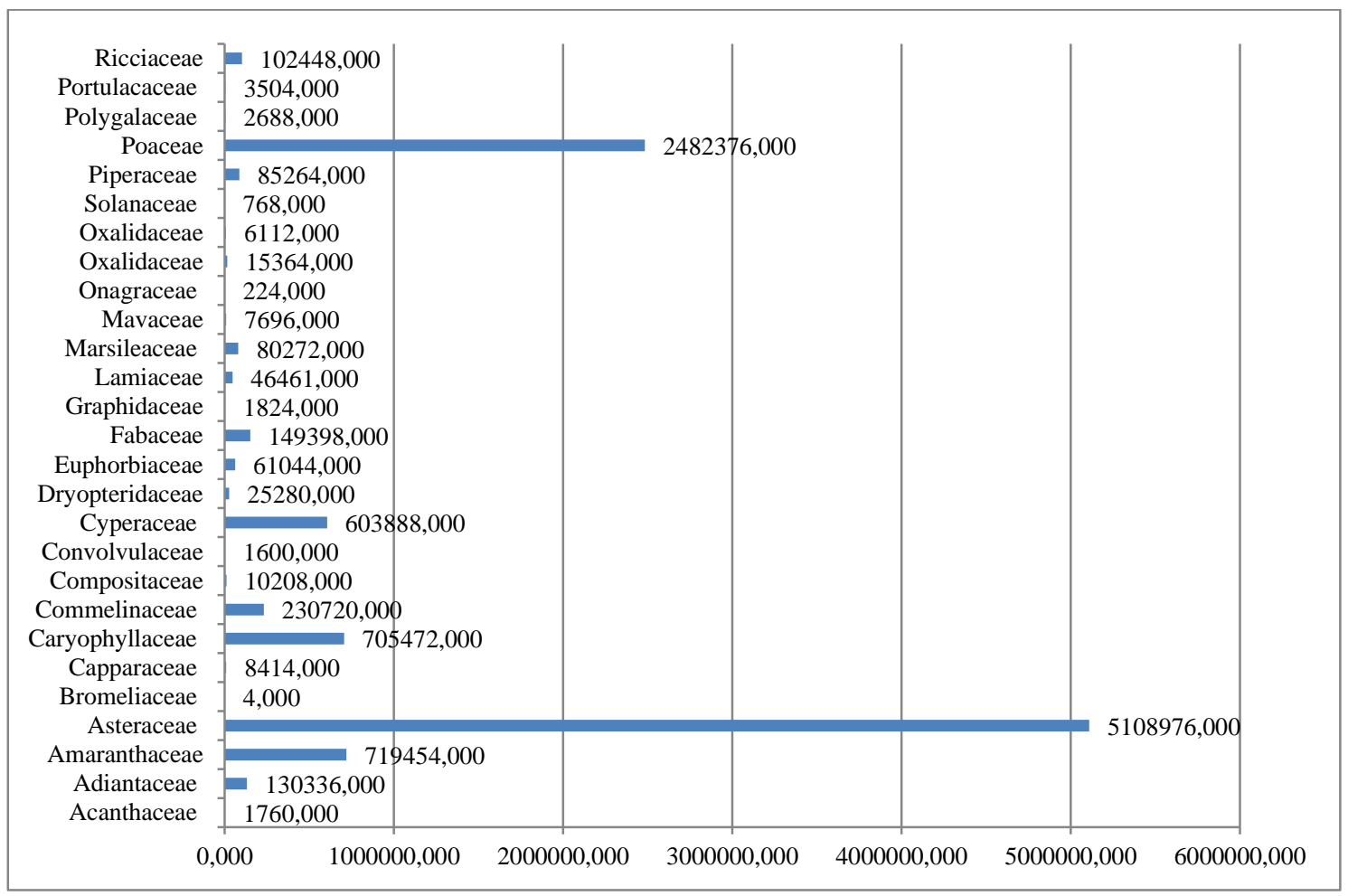

Gambar 2. Sebaran Densitas (per $400 \mathrm{~m}^{2}$ ) untuk Setiap Famili Vegetasi LCC 


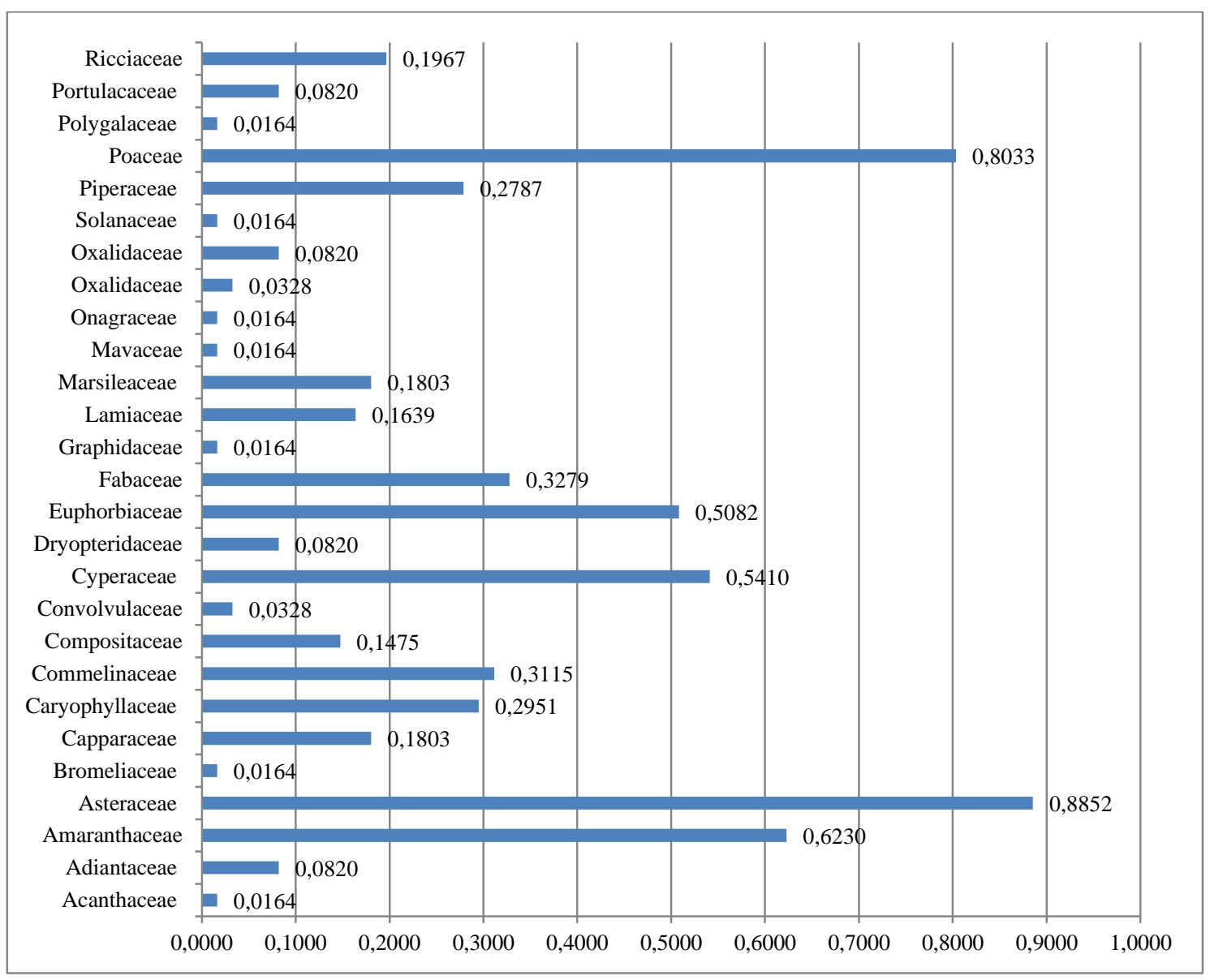

Gambar 3. Sebaran Frekuensi untuk Setiap Famili Vegetasi LCC

Pada Tabel 4, dapat diketahui pula besarnya INP yang menggambarkan do-minasi masing-masing spesies LCC pada lokasi penelitian. Berdasarkan perhitung-an tersebut, diketahui bahwa lokasi pene-litian didominasi oleh Widelia montana (INP: 39,716\%), Ageratum conyzoides (INP: 23, 340\%), Achyranthes aspera (IN P: 12,680\%), Pennisetum purpureum (IN P): 11,340\%), serta Drymaria chordata (INP: 10,031\%). Sedangkan jika dihitung tiap famili, maka lokasi penelitian dido-minasi oleh Asteraceae (INP: 63,112\%), Poaceae (INP: 36,936\%), Amaranthaceae (INP: 17,261\%), Cyperaceae (INP: 14,79 3\%), serta Caryophyllaceae (INP: 11,619\%). Sebaran INP untuk setiap famili disa-jikan pada Gambar 4. 


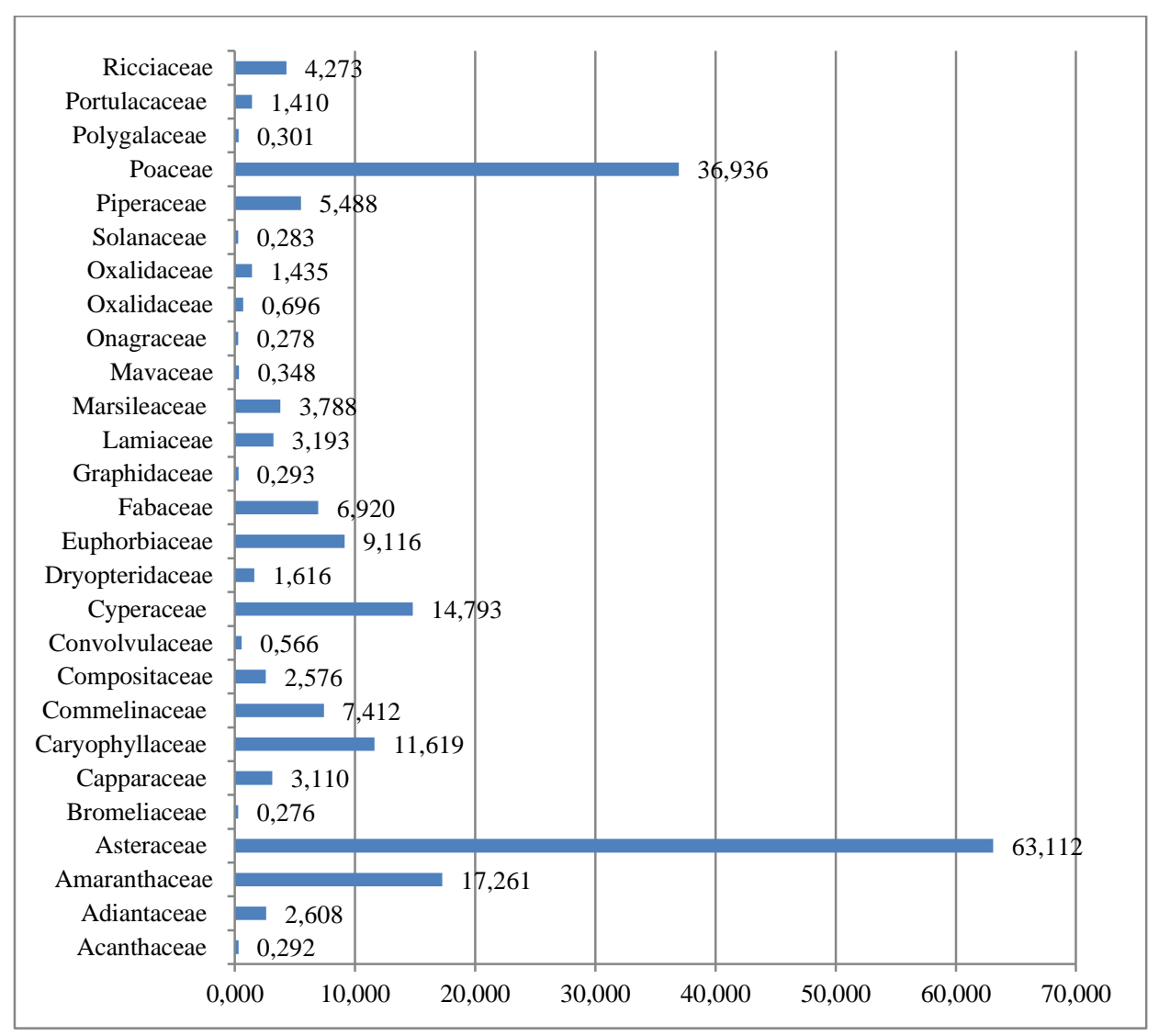

Gambar 4. Sebaran Indeks Nilai Penting (INP) Spesies LCC Tiap Famili

\section{Indeks Diversitas Vegetasi}

Keanekaragaman spesies merupa-kan ciri tingkatan komunitas berdasar-kan organisasi biologinya. Keanekaragaman spesies dapat digunakan untuk menyatakan struktur komunitas. Kea-nekaragaman spesies juga dapat digu-nakan untuk mengukur stabilitas komu-nitas, yaitu kemampuan suatu komu-nitas untuk menjaga dirinya tetap stabil meskipun ada gangguan terhadap kom-ponenkomponennya (Soegianto, 1994).

Dalam rangka memperkirakan ke-anekaragaman spesies, terdapat beberapa indeks keanekaragaman yang da-pat digunakan. Indeks yang digunakan pada penelitian ini adalah indeks kea-nekaragaman Shannon atau Shannon index of general diversity ( $\left.\mathrm{H}^{\prime}\right)$.

Pada analisis kuantitatif yang di-lakukan terhadap vegetasi pohon di lo-kasi kajian AMDAL kecamatan Ampel kabupaten Boyolali, diperoleh hasil per-hitungan indeks diversitasnya adalah 0,9864 , yang artinya bahwa nilai $\mathrm{H}^{\prime}<1$. Hal ini menunjukkan bahwa keaneka-ragaman spesies di lokasi penelitian rendah, tetapi mendekati sedang karena sangat dekat dengan nilai 1 . Sedangkan pada vegetasi penutup lantai atau LCC, diperoleh indeks diversitas atau keane-karagaman vegetasi LCC di lokasi pe-nelitian adalah 1,144822 yang artinya bahwa nilai $1 \leq$ $\mathrm{H} \leq 3$. Hal ini menun-jukkan bahwa keanekaragaman spesies dilokasi sedang melimpah.

\section{PEMBAHASAN}

Pada penelitian ini, parameter ve-getasi yang dianalisis secara kuantitatif antara lain densitas, frekuensi, indeks nilai penting (INP), dan indeks diversi-tas atau indeks keanekaragaman. Pem-bahasan penelitian ini difokuskan pada struktur dan komposisi vegetasi penyu-sun lokasi kajian AMDAL kecamatan Ampel kabupaten Boyolali serta meng-analisis pengaruh INP dan indeks diver-sitas terhadap lingkungan secara kese-luruhan.

Hasil pengamatan di lapangan ser-ta analisis kuantitatif terhadap vegetasi pohon menunjukkan bahwa lokasi pe-nelitian banyak didominasi oleh tanam-an pangan. Hal ini terlihat dari tumbu-han yang paling banyak ditemukan di beberapa titik di lokasi penelitian adalah tanaman pangan seperti cabe rawit, ketela pohon, jagung, dan pisang. Selain itu, terdapat pula lahan dengan tanaman produksi seperti sengon. Sedangkan spe sies tanaman LCC di lokasi penelitian berdasarkan jumlah individunya dido-minasi oleh spesies dari famili Asteraceae, Poaceae, Amaranthaceae, Caryo-phyllaceae, serta Cyperaceae. Jenis her-ba tersebut pada umumnya merupakan herba yang dimanfaatkan sebagai pakan ternak.

Berdasarkan data berupa frekuen-si, diperoleh hasil bahwa spesies dengan distribusi yang merata dan sering hadir di setiap plot adalah sengon (Albizzia falcata) 
sedangkan spesies LCC yang frekuensinya paling besar adalah Widelia montana. Frekuensi menunjuk-kan besarnya intensitas diketemukannya suatu spesies organisme dalam penga-matan keberadaan organisme pada ko-munitas atau ekosistem.

Soegianto (1994) menyatakan bah wa apabila pengamatan dilakukan pada petak-petak contoh, maka makin banyak petak contoh yang didalamnya ditemu-kan suatu spesies, berarti makin besar frekuensi spesies tersebut. Sebaliknya, jika makin sedikit petak contoh yang di dalamnya ditemukan suatu spesies ma-kin kecil frekuensi spesies tersebut. De-ngan demikian, sesungguhnya frekuensi tersebut dapat menggambarkan tingkat penyebaran spesies dalam habitat yang dipelajari meskipun belum dapat meng-gambarkan tentang pola penyebaran-nya. Spesies organisme yang penyeba-rannya luas akan memiliki nilai freku-ensi perjumpaan yang besar.

Berdasarkan analisis terhadap INP diketahui bahwa lokasi penelitian dido-minasi oleh spesies pohon Capsicum frutescens sedangkan LCC didominasi oleh Widelia montana. INP merupakan indeks yang dapat digunakan sebagai pembanding signifikansi ekologi dari su atu spesies dan dapat digunakan seba-gai dasar dalam menentukan dominansi spesies dalam ekosistem (Win, 2011). Spesies yang dominan dalam suatu ko-munitas tumbuhan akan memiliki in-deks nilai penting yang tinggi, sehingga spesies yang paling dominan tentu me-miliki INP yang besar.

Hasil analisis INP untuk vegetasi pohon menunjukkan lima spesies yang memiliki INP tertinggi yaitu Capsicum frutescens, Mannihot utilissima, Albizia falcata, Zea mays, dan Musa paradisia-ca. INP yang tinggi menunjukkan peran spesies dalam komunitas secara umum. Tanaman cabe rawit, ketela pohon, ja-gung dan pisang merupakan tanaman pangan yang sering dimanfaatkan oleh masyarakat di sekitar lokasi sehingga banyak ditemukan sedangkan sengon merupakan tanaman bernilai ekonomi tinggi (komersial) sehingga banyak di-kembangkan. Hal ini memperkuat per-nyataan bahwa INP memberikan penge-tahuan pada kita tentang pentingnya su-atu spesies dalam suatu komunitas atau ekosistem (Giliba, et.al., 2011).

Hasil perhitungan indeks diversi-tas menunjukkan bahwa nilai $H^{\prime}$ untuk vegetasi pohon adalah 0,9864 $\left(H^{\prime}<1\right)$ sedangkan untuk vegetasi LCC nilai $H^{\prime}$ adalah $1,144822\left(1 \leq H^{\prime} \leq 3\right)$. Hal ini me nunjukkan bahwa untuk vegetasi pohon indeks menunjukkan keanekaragaman yang rendah mendekati sedang sedang-kan untuk vegetasi LCC menunjukkan kondisi yang melimpah.

Keanekaragaman spesies dapat di gunakan untuk menyatakan struktur ko-munitas (Soegianto, 1994). Indeks di-versitas menurut Win (2011) merupakan perhitungan yang lebih baik untuk mem perkirakan keanekaragaman suatu lo-kasi dibandingkan hanya menghitung jumlah spesies saja. Stirling dan Wilsey (2001) menyatakan bahwa diversitas merupakan atribut komunitas yang berhubungan dengan stabilitas, produktivi-tas, dan struktur trofik. Keanekaragam-an yang diindikasikan dalam indeks di-versitas menurut Norman et.al (2005) merupakan poin penting dalam menja-ga keseimbangan proses-proses yang berlangsung dalam suatu ekosistem.

\section{KESIMPULAN}

Hasil penelitian menunjukkan bahwa untuk vegetasi pohon, diperoleh 46 spesies yang termasuk ke dalam 24 famili. Jenis pohon yang paling banyak ditemukan adalah Capsicum frutescens (cabe rawit) yang berjumlah 3655 individu tiap $1600 \mathrm{~m}^{2}$. Kontribusi spe-sies pohon yang terbesar ditunjukkan oleh indeks nilai penting (INP) tertinggi adalah Capsicum frutescens. Indeks diversitas/keanekaragaman vegetasi po-hon di lokasi adalah 0,9864 (rendah). Untuk vegetasi penutup lantai (LCC) ditemukan 80 spesies yang termasuk 27 famili. Cacah individu terbanyak adalah Wedelia montana sebanyak 3234608 individu per $400 \mathrm{~m}^{2}$. Indeks diversitas vegetasi LCC adalah 1,144822 (melim-pah).

\section{DAFTAR PUSTAKA}

Agustina, D.K. (2008). Studi Vegetasi di Hutan Lindung RPH Donomulyo BK PH Sengguruh KPH Malang. Skripsi tidak diterbitkan. Malang: Jurusan Biologi Fakultas Saintek UIN Mau-lana Malik Ibrahim Malang.

BKPM Kabupaten Boyolali. (2012). Peluang Investasi Daerah Kabupa-ten Boyolali. Boyolali: Badan Ko-ordinasi Penanaman Modal.

Fachrul, M.F. (2007). Metode Sampling Bioekologi. Jakarta: PT. Bumi Aksara.

Giliba, R.A., Boon, E.K., Kayombo, C.J., Musamba, E.B., Kashindye, A.M., Shayo, P.F. (2011). Species Composition, Richness, and Diver-sity in Miombo Woodland of Bere-ku Forest Reserve, Tanzania.

Indriyarto. 2008. Ekologi Hutan. Jakarta: Bumi Aksara.

Maarel, E.V.D. 2005. Vegetation Ecology. Victoria: Blackwell Publish-ing.

Maryantika, N., Lalu, M.J., Andie, S. (2010). Analisa Perubahan Vegetasi Ditinjau dari Tingkat Ketinggian dan Kemiringan Lahan Menggunakan Citra Satelit Landsat dan Spot 4 (Studi Kasus di Kabupaten Pasuru-han). (Online), (reposi tory.its.ac.id/ bitstream/...pdf) Diakses pada 30 Maret 2013.

Norman, W., H., Mason., D., Mouilliot, W.G., Lee, J.B., Wilson. (2005). Func-tional richness, functional evenness and functional divergence: the pri-mary components of functional di-versity. Oikos (111): 112-118.

Parejiya, N.B., Detroja, S.S, Pan-chal, N.S. (2013). Vegetation Analysis at Bandiyabedi Forest in Surendranagar District of Gujarat State of India. In-ternational Journal of Life Sciences Biotechnology and Pharma Rese-arch, 2(2): 241247.

Smith, P.L. Wilson, B., Nadolny, C., Lang, D. (2000). The Ecological Ro-le of The Native Vegetation of New South Wales. New South Wales: Native Vegetation Advisory Coun-cil. 
Stirling, G., \& Wilsey B. (2001). Empirical Relationships between Species Rich-ness, Evennes, and Proportional Diversity. The American Naturalist 158 (3): 286-299.

Soegianto, A. (1994). Ekologi Kuantitatif Metode Analisis Populasi dan Komunitas. Jakarta: Penerbit Usaha Nasional.

Susanto, W. (2012). Analisis Vegetasi pada Ekosistem Hutan Hujan Tropis untuk Pengelolaan Kawasan Taman Hutan
Raya Raden Soerjo (Wilayah Pengelolaan Cangar-Kota Batu). (Online), 30/ 03/2013.

Win, N. (2011). Quantitative Analysis of Forest Structure in the Middle Part of the Goktwin Area, Northern Shan State. Universities Research Hiyrbak 4(1): 321-335. 